\title{
Pengembangan sistem informasi berbasis komputer untuk efisiensi penyelenggaraan makanan di Instalasi Gizi RS Militer Malang
}

\author{
Hasan Aroni', Hari Kusnanto², Anis Fuad²
}

\begin{abstract}
Background: The rapid development of science and technology in the globalization era, particularly information technology enables data or information to be processed quickly and accurately. Nutrition service in the form of food provision in hospitals requires precision and accuracy as well as speed in its process. Therefore the utilization of science and technology especially computer-based information system will be of much help. Nutrition installation of Malang Military Hospital still uses manual method in calculating the need for food stock so that it needs more time and nutrition staff to do the work.

Method: The study was a quasi experimental study (before and after) without control group to find out the difference in duration of food stock need calculation before and after the implementation of computer-based information system in the food provision at Nutrition Installation of Malang Military Hospital.

Result: The implementation of computer-based information system at nutrition installation improved nutrition staff and time efficiency in the calculation of food stock needs. Only one nutrition staff was needed to operate computer, whereas in the manual calculation method two nutrition staff were needed to do the work. The time needed to calculate food stock before the implementation of computer-based information system in average was 3.5 hours and after the implementation was 1.6 hours, based on statistical test at significance level $95 \% p<\alpha(0.05)$ whereby $0.003<0.05$. This meant there was difference in duration of time needed before and after the implementation of computer-based information system in food provision at Nutrition Installation of Malang Military Hospital.

Conclusion: The development of computer-based information system improved nutrition staff and time efficiency in the calculation of food stock need in food provision at Nutrition Installation of Malang Military Hospital.
\end{abstract}

KEYWORDS: information system, efficiency, food stock calculation, nutrition installation, food provision

\begin{abstract}
ABSTRAK
Latar Belakang: Perkembangan iptek pada era globalisasi yang begitu pesat, terutama teknologi informasi akan memungkinkan proses data atau informasi dengan cepat dan akurat. Pelayanan gizi, dalam hal penyelenggaraan makanan rumah sakit dalam prosesnya memerlukan ketelitian dan ketepatan serta kecepatan waktu yang digunakan. Untuk itu, pemanfaatan ilmu pengetahuan dan teknolgi dalam hal ini sistem informasi berbasis komputer akan sangat membantu. Instalasi Gizi Rumah Sakit Militer Malang (RSMM), dalam kegiatan perhitungan kebutuhan bahan makanan masih menggunakan penghitungan secara manual sehingga memerlukan waktu dan tenaga kerja gizi yang lebih untuk menyelesaikannya.

Tujuan: Mengembangkan sistem informasi berbasis komputer untuk meningkatkan efisiensi waktu dan tenaga kerja gizi dalam perhitungan kebutuhan bahan makanan pada penyelenggaraan makanan di Instalasi Gizi RSMM.

Metode: Penelitian ini merupakan penelitian quasi experimental (before-after) tanpa kelompok kontrol untuk mengetahui perbedaan durasi waktu yang digunakan dalam perhitungan kebutuhan bahan makanan sebelum dan sesudah menerapkan sistem informasi berbasis komputer pada penyelenggaraan makanan di Instalasi Gizi RSMM.

Hasil: Penelitian ini menunjukkan bahwa dengan penerapan sistem informasi berbasis komputer pada instalasi gizi akan meningkatkan efisiensi tenaga kerja gizi dan waktu dalam perhitungan kebutuhan bahan makanan. Satu tenaga kerja gizi cukup digunakan untuk operasional computer yangsebelumnya 2 tenaga kerja gizi untuk perhitungan secara manual. Waktu yang diperlukan untuk perhitungan bahan makanan sebelum dan sesudah menerapkan sistem informasi berbasis komputer berbeda nyata dengan rata-rata adalah 3,5 jam dan 1,6 jam $(p<0,05)$.

Kesimpulan: Pengembangan sistem informasi berbasis komputer akan meningkatkan efisiensi tenaga kerja gizi dan waktu dalam perhitungan kebutuhan bahan makanan pada penyelenggaraan makanan di Instalasi Gizi RSMM.
\end{abstract}

KATA KUNCI: sistem Informasi, komputer, efisiensi tenaga kerja gizi dan waktu, perhitungan kebutuhan bahan makanan

${ }^{1}$ Politeknik Kesehatan Malang, Jl. Besar ljen 77C Malang, Jawa Timur, email: hasanaroni@yahoo.co.id

${ }^{2}$ Minat Utama Sistem Informasi Manajemen Kesehatan, Program Pascasarjana IImu Kesehatan Masyarakat Fakultas Kedokteran UGM, JI. Farmako,

Sekip Utara, Yogyakarta 55281, email: anisfuad@ugm.ac.id 


\section{PENDAHULUAN}

Memasuki era globalisasi yang ditandai dengan adanya persaingan pada berbagai aspek, diperlukan sumber daya manusia (SDM) yang berkualitas tinggi agar mampu bersaing dengan negara lain. Kesehatan dan gizi merupakan faktor penting karena secara langsung berpengaruh terhadap kualitas SDM di suatu negara yang digambarkan melalui pertumbuhan ekonomi, umur harapan hidup, dan tingkat pendidikan. Tingkat pendidikan yang tinggi hanya dapat dicapai oleh orang yang sehat dan berstatus gizi baik. Oleh karena itu, diperlukan upaya perbaikan gizi dalam keluarga maupun pelayanan gizi pada individu dan populasidi institusi pelayanan kesehatan seperti rumah sakit (1).

Pelayanan gizi merupakan bagian integral dari pelayanan kesehatan di rumah sakit yang saling menunjang dan tidak dapat dipisahkan dengan pelayanan lain. Pelayanan gizi yang bermutu di rumah sakit akan membantu mempercepat proses penyembuhan pasien, yang berarti pula memperpendek lama hari rawat sehingga dapat menghemat biaya pengobatan. Hal ini sejalan dengan perkembangan iptek (ilmu pengetahuan dan teknologi) di bidang kesehatan, salah satunya adalah telah berkembang terapi gizi medis yang merupakan kesatuan dari terapi medis, asuhan keperawatan, dan asuhan gizi (1).

Kegiatan pokok pelayanan gizi di rumah sakit terdiri dari asuhan gizi pasien rawat jalan, asuhan gizi pasien rawat inap, penyelenggaraan makanan, serta penelitian dan pengembangan gizi. Di dalam mekanisme kerja penyelenggaraan makanan, terdapat proses perhitungan kebutuhan bahan makanan yang digunakan untuk menyusun kebutuhan bahan makanan yang diperlukan untuk pengadaan bahan makanan (1).

Dalam proses perhitungan kebutuhan bahan makanan, diperlukan data serta informasi untuk dapat diproses lebih lanjut sampai menghasilkan kebutuhan bahan makanan yang diperlukan untuk pengadaan bahan makanan. Perkembangan iptek pada era globalisasi yang begitu pesat, terutama perkembangan komunikasi dan jaringan komputer menyebabkan arus informasi dapat mengalir dengan cepat. Semua perkembangan tersebut makin membuat informasi menjadi sumber daya yang sangat berharga dan perlu dikelola dengan cermat (2).

Guley dan Stinson (3) melaporkan bahwa keuntungan dari penggunaan algoritma dalam komputer pada pelayanan makan di Rumah Sakit Syracuse, New York dapat meminimalkan waktu antara menyediakan bahan makanan sampai penyajian pada konsumen.Sejalan dengan penelitian di atas, Golzynski dan Cash(4)juga menyatakan bahwa formula matematika pada teknologi informasi berbasis komputer dapat memudahkan manajemen pelayanan makanan. Meriwati dan Haksama(5) dalam penelitiannya melaporkan bahwa perencanaan kebutuhan bahan makanan merupakan salah satu langkah penting dalam upaya pengendalian biaya makan pasien. Ketepatan dalam memperkirakan kebutuhan bahan makanan sangat membantu terlaksananya pengadaan makanan yang lancar dan baik.

Instalasi Gizi Rumah Sakit Militer Malang (RSMM) mempunyai 5 ahli gizi dalam menjalankan kegiatan gizi rumah sakit, yaitu 2 orang di bagian poli gizi (rawat jalan) serta rawat inap, 1 orang di bagian produksi, 2 orang di bagian perencanaan dan administrasi gizi. Kegiatan perencanaan kebutuhan bahan makanan di instalasi gizi dalam menetapkan kebutuhan bahan makanan masih menggunakan penghitungan secara manual. Berdasarkan pengamatan, komputer yang tersedia sebanyak 1 unit namun belum dimanfaatkan dengan maksimal untuk proses perhitungan kebutuhan bahan makanan. Siklus menu yang digunakan adalah siklus menu 10 hari.Kegiatan rutin perencanaan kebutuhan bahan makanan memerlukan tenaga setiap hari sebanyak 2 orang ahli gizi.Kegiatan ini dilakukan mulai pukul 07.30-11.00 WIB. Dengan jumlah pasien rata-rata perhari 130 orang, proses perencanaan penetapan kebutuhan bahan makanan secara manual memerlukan waktu sekitar 3,5 jam perhari.

Berdasarkan latar belakang tersebut, penelitian ini bertujuan mengembangkan sistem informasi berbasis komputer untuk meningkatkan efisiensi waktu dan tenaga kerja dalam perhitungan kebutuhan bahan makanan pada penyelenggaraan makanan di Instalasi Gizi RSMM.

\section{BAHAN DAN METODE}

Penelitian ini merupakan penelitian quasi experimental (before-after) tanpa kelompok kontrol untuk mengetahui perbedaan durasi waktu yang digunakan dalam perhitungan kebutuhan bahan makanan sebelum dan sesudah mengembangkan sistem informasi berbasis komputer pada penyelenggaraan makanan di RSMM.

Subjek penelitian adalah ahli gizi yang bertugas di bagian perencanaan pada RSMM sebanyak2 orang. Pengambilan data dilakukan sebelum dan sesudah pengembangan sistem informasi berbasis komputer dalam perhitungan kebutuhan bahan makanan pada penyelenggaraan makanan di RSMM.

Data sebelum dan sesudah penerapan sistem informasi berbasis komputer berupa durasi waktu dianalisis secara kuantitatif dengan menggunakan uji statistik parametrik $T$-test untuk mengetahui perbedaan dalam perhitungan kebutuhan bahan makanan sebelum dan sesudah mengembangkan sistem informasi berbasis komputer pada penyelenggaraan makanan di RSMM. Seluruh teknis pengolahan data dikerjakan dan dianalisis dengan bantuan komputer. 


\section{HASIL DAN BAHASAN}

\section{Sistem informasi di instalasi gizi}

Sistem informasi yang digunakan di Instalasi Gizi RSMM adalah konvensional (manual), mulai dari perhitungan kebutuhan bahan makanan sampai dengan pemesanan. Hal ini dipengaruhi oleh tidak tersedianya software aplikasi penggunaan komputer yang masih rendah (hanya untuk ketik surat). Dengan demikian, tenaga yang diperlukan menjadi lebih dari satu orang dan waktu pengerjaan menjadi lebih lama. Menurut Setiawan (6), komputer dapat digunakan manusia untuk memproses pemecahan masalah. Langkah-langkah perhitungan kebutuhan bahan makanan sampai pada pemesanan di RSMM dapat dilihat pada Gambar 1.

Informasi mengenai jumlah pasien, macam diet, dan perhitungan kebutuhan bahan makanan (perencanaan bahan makanan) termasuk pemesanan seringkali kurang tepat dan akurat karena kesalahan penulisan dan perhitungan. Hal ini menyebabkan keputusan yang diambil dalam pemesanan bahan makanan menjadi kurang lancar. Perencanaan kebutuhan bahan makanan merupakan salah satu langkah penting dalam upaya pengendalian biaya makan pasien (5). Ketepatan dalam memperkirakan kebutuhan bahan makanan sangat membantu terlaksananya pengadaan makanan yang lancar dan baik. Peralatan komputer menyediakan kecerdasan untuk membantu membuat keputusan untuk kemajuan dari jasa dan teknologi informasi (7).
Informasi merupakan hasil dari pengolahan data dalam suatu bentuk yang lebih berguna dan lebih berarti bagi penerimanya yang menggambarkan suatu kejadiankejadian yangnyata yang digunakan untuk pengambilan keputusan (8). Pada dasarnya, orang dapat membangun suatu sistem informasi tanpa komputer, tetapi kemampuan computer membuat suatu sistem informasi terwujud lebih efisien(9). Pengelolaan data tak selamanya harus dengan komputer, bisa juga secara manual, walaupun lebih lama dan sulit (10).

\section{Penyelenggaraan makanan di RSMM}

Penyelenggaraan makanan rumah sakit adalah suatu rangkaian kegiatan mulai dari perencanaan menu sampai dengan pendistribusian makanan kepada konsumen, dalam rangka pencapaian status kesehatan yang optimal melalui pemberian diet yang tepat. Dalam hal ini termasuk kegiatan pencatatan, pelaporan, dan evaluasi (1).

Penyelenggaraan makanan di RSMM bertujuan untuk mendukung dan mempercepat kesembuhan pasien. Hal ini dibuktikan dengan adanya pembedaan menu untuk jenis diet yang berbeda. Namun belum semua jenis diet memiliki menu tersendiri. Jenis diet yang ada adalah diet DM (diabetes mellitus), hati, RG (rendah garam), RP (rendah protein), RKol (rendah kolesterol), dan TETP (tinggi energi tinggi protein). Hal ini disebabkan oleh jenis diet yang paling sering ada adalah seperti diet DM, hati, RG, RP, RKol, dan TETP, sehingga jika ada jenis diet yang lain maka sifatnya temporer dan akan dibuatkan saat itu juga.

Pasien ruang rawat inap dietnya ditulis pada bon pemesanan makanan pasien di tiap-tiap ruang rawat berdasarkan buku diet ruangan

Pada bagian perencanaan gizi, bon makanan direkap berdasarkan status
pasien (dinas, askes, swasta). Rekapitulasi pasien diuraikan sesuai kelas
perawatan dan macam diet

Hasil dari rekapan dapat diketahui jumlah pasien yang mendapat makanan biasa, lunak, saring, makanan lewat pipa (MLP), diet khusus, tinggi energi tinggi protein (TETP)
Siklus menu sehari yang digunakan untuk keesokan harinya ditulis pada lembar menu sehari dilengkapi pedoman menu dan standar porsi yang digunakan

Membuat daftar pemesanan bahan makanan (rangkap 2) setiap status pasien berdasarkan jumlah pasien, jenis diet dan standar menu yang digunakan, termasuk pedoman menu dan standar porsi

Lembar pemesanan bahan makanan harian direkap ulang ke dalam pemesanan bahan makanan bulanan (1 bulan). Setelah berjalan setiap 1 bulan, jumlah kebutuhan bahan makanan ditotal 
Penyelenggaraan makanan di RSMM dimulai dari perencanaan menu, perhitungan kebutuhan bahan makanan, pemesanan dan pembelian bahan makanan, penerimaan, penyimpanan dan penyaluran bahan makanan, persiapan bahan makanan, pengolahan bahan makanan dan distribusi makanan ke pasien. Semua kegiatan mulai dari perhitungan kebutuhan bahan makanan sampai ke pemesanan di lakukan secara manual. Pelaksanaan penyelenggaraan makanan rumah sakit harus dipandang sebagai program yang utuh, yang harus dikelola secara profesional.Pengelolaan makanan itu sendiri sebenarnya berfungsi sebagai sistem yang terpadu dan terintegrasi dengan subsistemnya, yaitu perencanaan menu, taksiran kebutuhan bahan makanan, pengadaan bahan makanan, penerimaan dan penyimpanan, persiapan dan perlengkapan, tenaga yang tepat dan pengawasan harga makanan (11).

\section{Pengembangan sistem informasi berbasis komputer}

Pengembangan sistem informasi yang dilakukan di bagian perencanaan pada instalasi gizi melalui beberapa tahapan dalam pembuatannya.Pengembangan sistem informasi yang direalisasikan dengan bantuan komputer (computerized information system) melalui suatu tahapan yang disebut dengan sistem analisis dan desain. Sebelum sistem dapat didesain untuk memperoleh data, menghasilkan laporan-laporan, terlebih dahulu diketahui tentang cara bagian perencanaan instalasi gizi menangani operasi-operasinya, formulir yang digunakan, cara mengisinya serta hal yang dilaporkan.

Melalui proses pengidentifikasian, kebutuhan organisasi yaitu pentingnya komputerisasi dalam instalasi gizi khususnya bagian perencanaan untuk memanfaatkan komputer guna mempercepat proses perhitungan kebutuhan bahan makanan, maka dikembangkan suatu prototype software aplikasi dengan mengggunakan dasar microsoft excel 2003 dan visual basic for application (VBA). Untuk selanjutnya,software aplikasi ini disebut dengan PKBM (perhitungan kebutuhan bahan makanan). Tahapan pengembangan sistem informasi berbasis komputer dapat dilihat pada Gambar 2.

Pengembangan sistem informasi yang direalisasikan dengan bantuan komputer berguna dalam peningkatan kinerja suatu organisasi untuk perbaikan prosedurprosedur dan metode yang lebih baik. Informasi dapat berguna jika didukung oleh tiga pilar, antara lain: tepat pada orangnya atau relevan, tepat waktu, dan tepat nilainya atau akurat. Hasil yang tidak didukung oleh ketiga pilar ini tidak dapat dikatakan sebagai informasi yang tidak berguna (12). Suatu sistem informasi dapat berupa kombinasi yang terorganisir dari orang, perangkat keras, perangkat lunak, jaringan komunikasi, dan sumber data yang terkumpul, transformasi, dan memberikan informasi pada suatu organisasi (13).

Mengamati dan menanyakan langkah demi langkah proses perhitungan kebutuhan bahan makanan yang dilakukan secara manual, termasuk form-form yang digunakan dan yang dilaporkan

Mengembangkan sistem informasi berbasis komputer dengan merancang basis data, form input data, menggunakan program aplikasi Microsoft Office Excel 2003 dan Visual Basic for Application

Membuat tampilan antar muka dengan bantuan Visual Basic for Application serta Configuration Settings agar menempel pada program file pada drive aktif dengan menggunakan Instal Creator

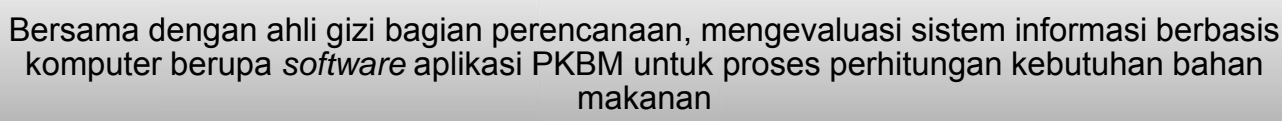

Melakukan uji coba software aplikasi bersama dengan ahli gizi bagian perencanaan

Memperbaiki kekurangan software aplikasi PKBM

Menggunakan software aplikasi PKBM dalam kegiatan operasional

Gambar 2. Tahapan pengembangan sistem informasi berbasis komputer 
Pengembangan sistem informasi dengan bantuan komputer berupa software aplikasi PKBM menggunakan metode ini perlu dikembangkan karena Instalansi Gizi RSMM selama ini melakukan perhitungan kebutuhan bahan makanan secara konvensional. Metode prototype cocok digunakan sebagai metode pengembangan sistem informasi manajemen (SIM) bagi organisasi yang mempunyai sistem yang inovatif, misalnya organisasi yang sudah lama menggunakan sistem manajemen yang konvensional akan mencoba menerapkan manajemen metode baru (2).

Dengan tersedianya software aplikasi PKBM, pemesanan untuk pembelian bahan makanan, sistem peramalan/taksiran telah tersedia dan daftar bahan makanan sudah tersedia. Hal ini sesuai dengan penelitian yang menyatakan bahwa pemesanan untuk pembelian bahan makanan, peramalan/taksiran dan daftar bahan makanan sudah tersedia (14), sehingga proses tersebut dapat dilakukan dengan menggunakan komputer.Cara kerja software aplikasi PKBM dapat dilihat pada Gambar 3-8.

Untuk pasien DM, yang dibedakan adalah jenis sayur, buah, dan snack yang diberikan, sedangkan untuk jumlah nasi mengikuti standar makanan biasa, dikurangi dan ditambahkan yang disesuaikan dengan jenis diet DM yang direkomendasikan dokter, begitu pula untuk TETP yang diberikan adalah sebanyak 2.500 kalori. Hal ini merupakan kebijakan yang ditetapkan oleh rumah sakit.

Penggunaan Microsoft Office Excel sebagai dasar pembuatan software aplikasi PKBM memiliki beberapa kelebihan antara lain pengoperasiannya yang relatif mudah dan fleksibel, namun juga memiliki kelemahan yaitu adanya kemungkinan salah meletakkan entri ke kolom yang tidak tepat yang akan berakibat kesalahan dalam hasil, sehingga diperlukan ketelitian dan ketepatan dalam mengentri data.

\section{Efisiensi waktu dan tenaga}

Dengan menggunakan software aplikasi PKBM dalam operasional perhitungan kebutuhan bahan makanan, tenaga gizi yang semula dua orang dalam perencanaan, berkurang menjadi satu orang saja sebagai operator dalam menjalankan program, sedangkan waktu yang diperlukan dalam proses perhitungan kebutuhan bahan makanan di RSMM sebelum menggunakan menggunakan software aplikasi PKBM rata-rata adalah 210 menit atau 3,5 jam dan setelah menggunakan software aplikasi PKBM rata-rata adalah 96 menit atau 1,6 jam, jadi selisih waktu yang digunakan adalah 114 menit atau

Mengisi tanggal sesuai dengan tanggal yang berlaku hari yang bersangkutan

Entri data kekuatan pasien sesuai dengan kekuatan pasien yang diperoleh dari Pelayanan Medik (YanMed)

Merekap jumlah pasien dinas, swasta, askes, dan gakin berdasarkan jumlah dietnya

Jumlah produksi hari ini secara otomatis berdasarkan jumlah pasien dinas, swasta, askes dan gakin berupa jumlah nasi, tim, bubur, tim saring, lauk cincang jumlah diet yang ada serta kebutuhan beras

Jumlah bahan makanan yang diperlukan secara otomatis pada hari itu untuk pasien dinas, swasta, askes dan gakin berdasarkan pada menu yang digunakan serta standar porsinya dan masing-masing dietnya

Jumlah pesanan bahan makanan harian secara otomatis

Jumlah pesanan bahan makanan harian secara otomatis tercantum ke dalam rekapan bahan makanan bulanan

Gambar 3. Cara kerja software aplikasi perhitungan kebutuhan bahan makanan (PKBM) 
1,9 jam. Hasil pengamatan durasi waktu sebelum dan sesudah menggunakan software aplikasi PKBM seperti terlihat pada Gambar 9.

Sebelum menggunakan software aplikasi PKBM, waktu yang dipakai untuk menyelesaikan perhitungan kebutuhan bahan makanan rata-rata adalah 210 menit atau 3,5 jam, setelah menggunakan software aplikasi PKBM maka waktu yang dipakai untuk menyelesaikan perhitungan kebutuhan bahan makanan menurun menjadi rata-rata96 menit atau 1,6 jam. Hal ini sesuai dengan penelitian yang menyatakan bahwa digunakannya komputer dalam sebuah sistem informasi memiliki keunggulan yaitu proses pengolahan yang cepat (9).
Di samping itu, tenaga yang ada dapat lebih difungsikan untuk kegiatan lain yang diperlukan, yaitu sebelumnya perhitungan kebutuhan bahan makanan memerlukan 2 orang tenaga perencana gizi, maka setelah tersedianya software aplikasi PKBM ini, tenaga yang diperlukan untuk perencanaan dalam hal perhitungan kebutuhan bahan makanan menjadi 1 orang saja. Dalam sistem informasi yang berbasis komputer, hanya memerlukan seorang operator saja untuk menjalankannya, sehingga personal-personal yang lain yang sebelumnya terlibat dalam proses secara manual bisa difungsikan dan didayagunakan untuk tugas-tugas yang lain yang tentunya lebih perlu, namun demikian terdapat kemungkinan adanya

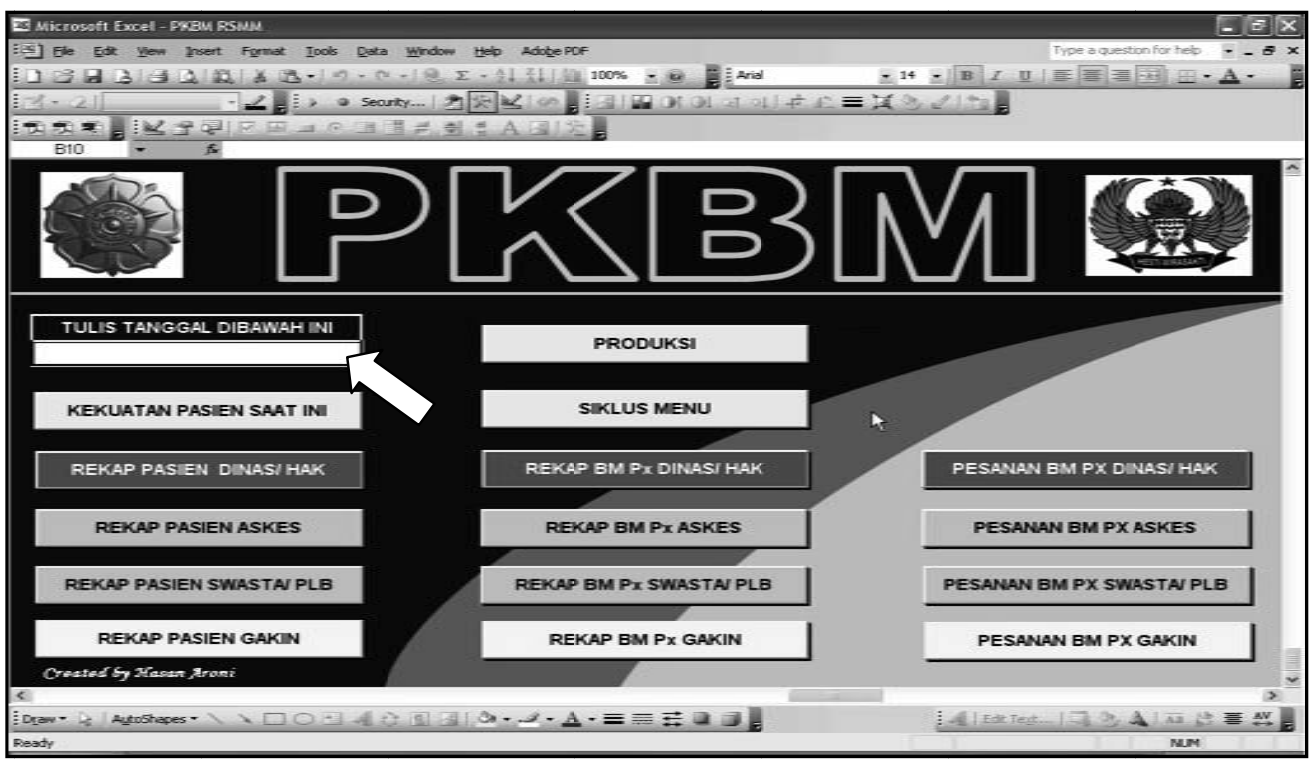

Gambar 4.Tampilan muka software aplikasi perhitungan kebutuhan bahan makanan (PKBM)

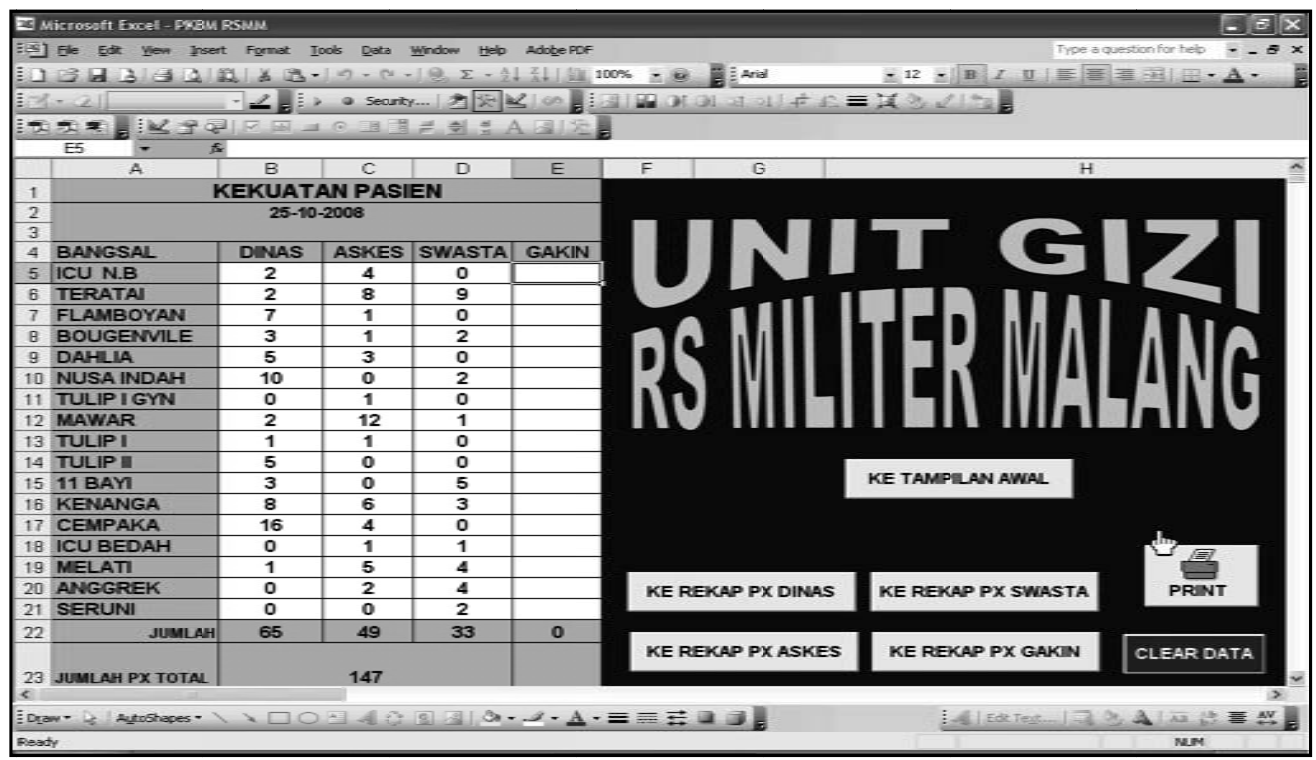

Gambar 5.Tampilan entri data kekuatan pasien pada software aplikasi perhitungan kebutuhan bahan makanan (PKBM) 
faktor yang dapat mempengaruhi perubahan tersebut yaitu jumlah komputer yang tersedia hanya satu unit. Hal ini sesuai dengan penelitian yang menyatakan bahwa perubahan yang terjadi karena adanya interaksi sosial yang komplek sebagai cerminan dari pengguna sistem (15).

\section{Analisis perubahan durasi waktu yang diperlukan sebelum dan sesudah menggunakan software aplikasi PKBM}

Hasil analisis dengan menggunakan bantuan komputer mengenai perubahan durasi waktu yang diperlukan untuk perhitungan kebutuhan bahan makanan sebelum dan sesudah menggunakan sistem informasi berbasis komputer (software aplikasi PKBM) pada penyelenggaraan makanan di RSMM, dengan tingkat kepercayaan $95 \%$ di dapatkan nilai $p<0,05$. Hal ini berarti terdapat perbedaan sebelum dan sesudah menerapkan sistem informasi berbasis komputer pada penyelenggaraan makanan di RSMM.

Pada penelitian ini, terdapat perbedaan durasi waktu yang digunakan sebelum dan sesudah menggunakan software aplikasi PKBM.Dengan penggunaan software tersebut,waktu yang dperlukan menjadi lebih singkat. Digunakannya komputer dalam sebuah sistem informasi menjadikan proses pengolahan berlangsung cepat(9).

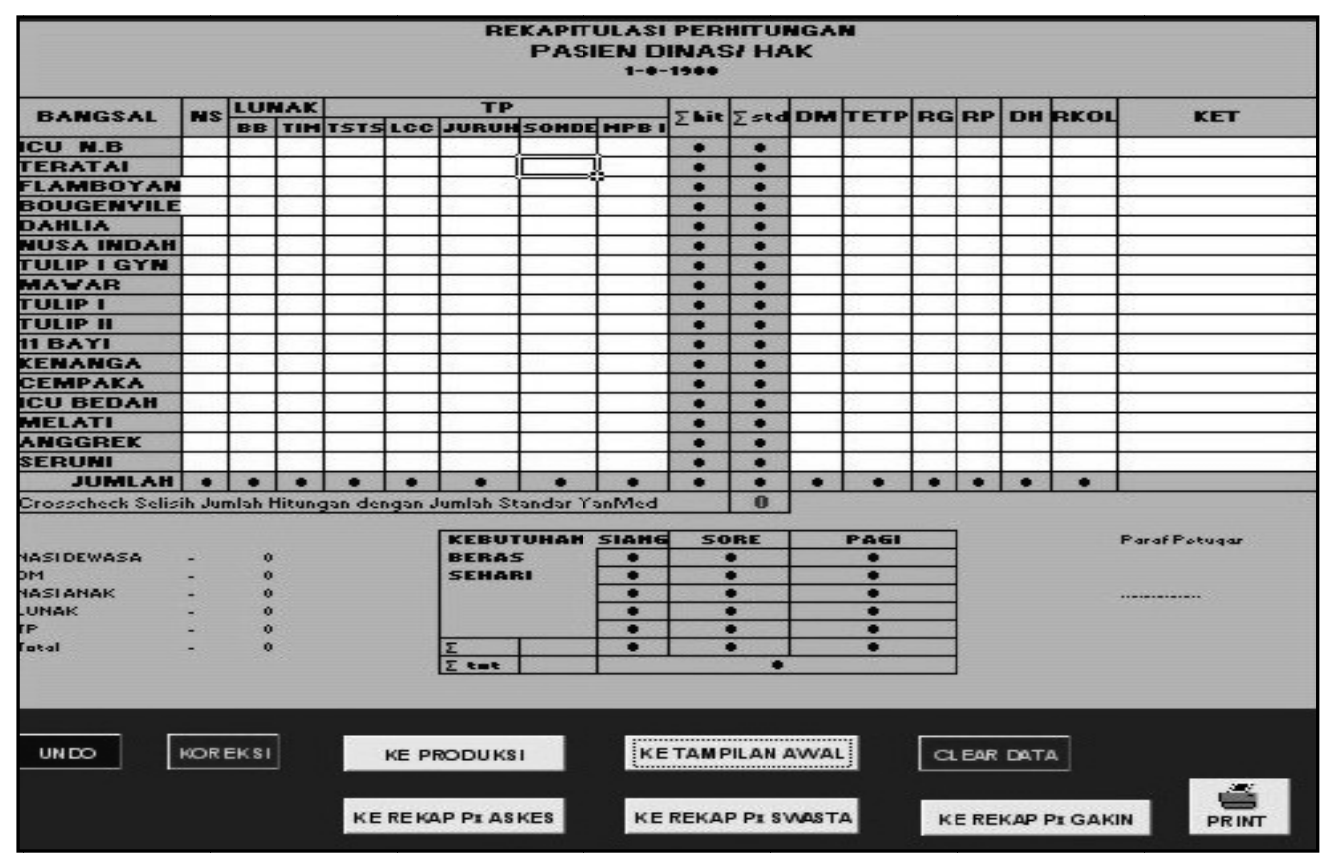

Gambar 6. Tampilan entri data rekapitulasi perhitungan pasien dinas

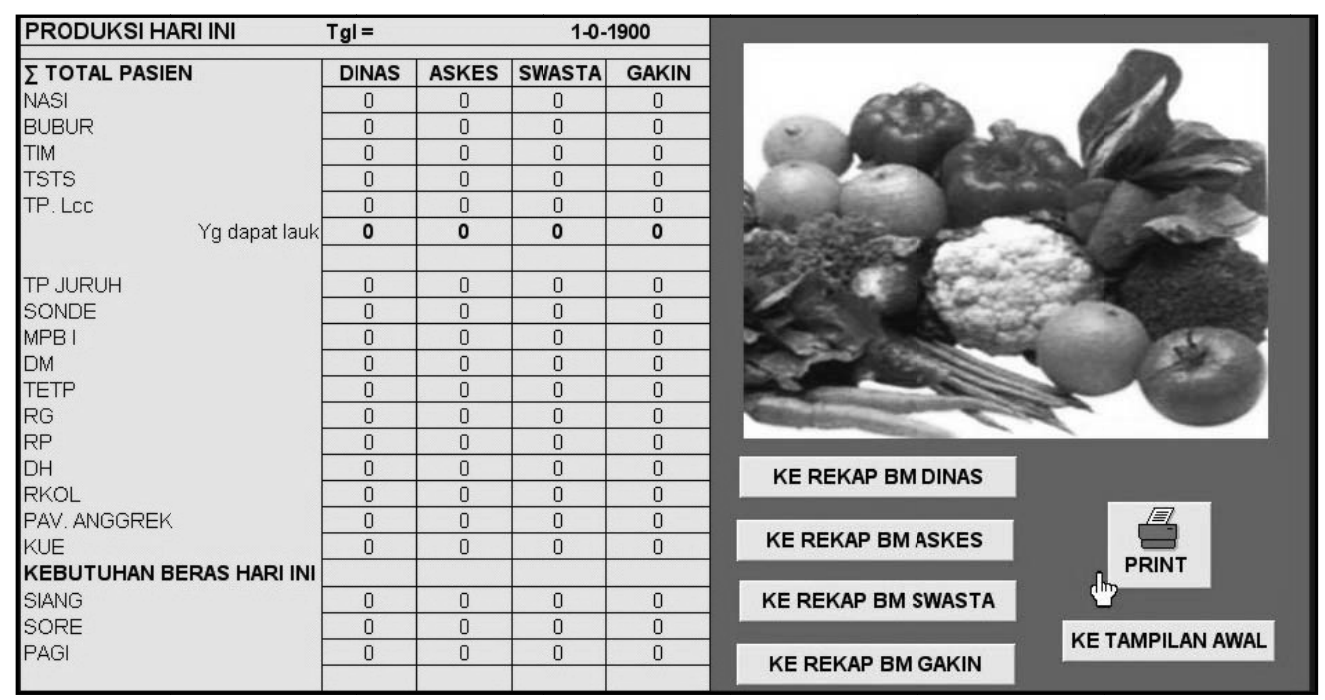

Gambar 7. Tampilan jumlah produksi pada software aplikasi perhitungan kebutuhan bahan makanan(PKBM) 


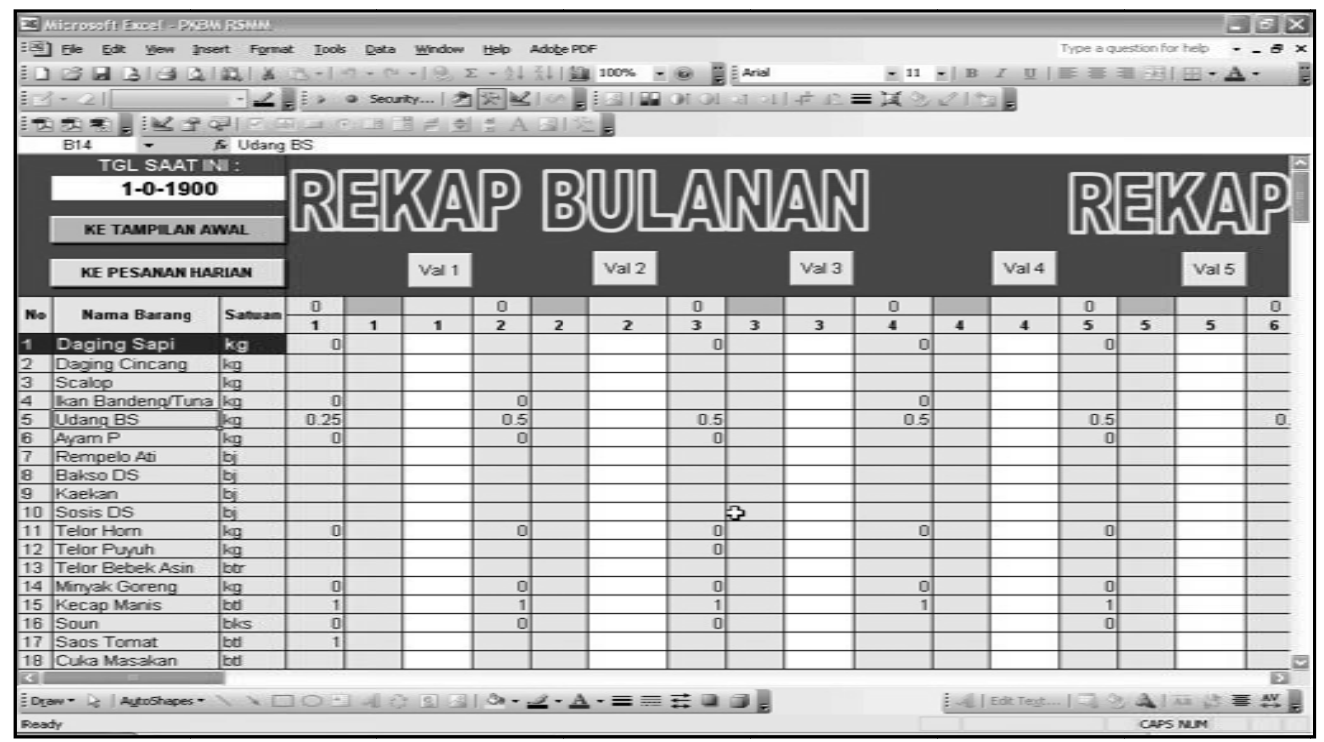

Gambar 8. Tampilan jumlah bahan makanan yang diperlukan pada software aplikasi perhitungan kebutuhan bahan makanan (PKBM)

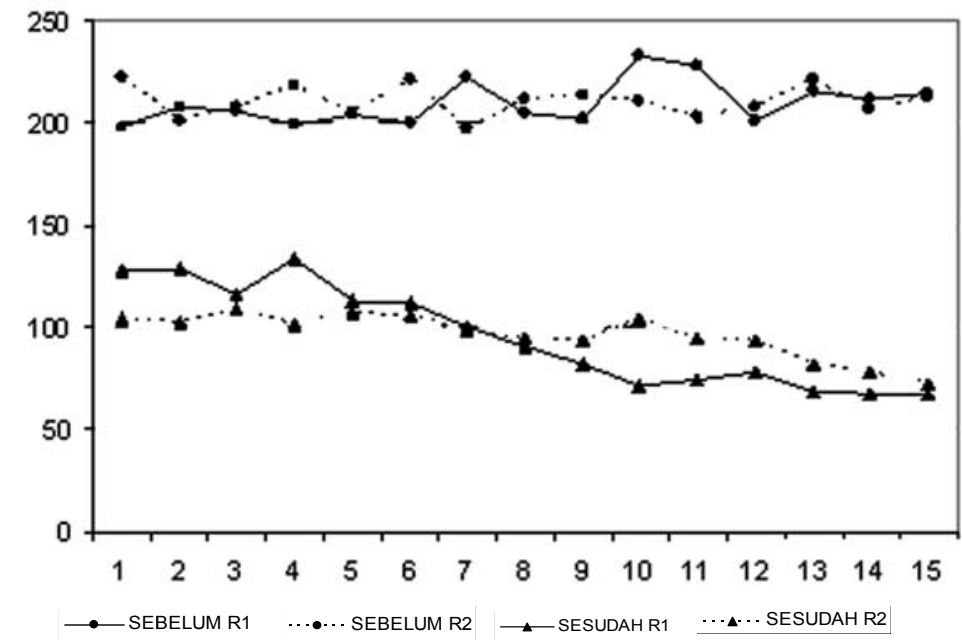

Gambar 9. Hasil pengamatan durasi waktu sebelum dan sesudah menggunakan software aplikasi perhitungan kebutuhan bahan makanan (PKBM)

Keuntungan dari penggunaan algoritma dalam komputer pada pelayanan makan di Rumah Sakit Syracuse, New York dapat meminimalkan waktu antara menyediakan bahan makanan sampai penyajian pada konsumen. Sejalan dengan penelitian di atas, formula matematika pada teknologi informasi berbasis komputer pada manajemen pelayanan makanan menjadikannya mudah (4). Ketepatan dalam memperkirakan kebutuhan bahan makanan sangat membantu terlaksananya pengadaan makanan yang lancar dan baik(5).

\section{KESIMPULAN DAN SARAN}

Berdasarkan pembahasan di atas, dapat disimpulkan bahwa pengembangan sistem informasi berbasis komputer pada penyelenggaraan makanan di RSMM menghasilkan software aplikasi PKBM yang bermanfaat dalam efisiensi waktu, tenaga gizi, dan penyediaan data elektronik sehingga mampu meningkatkan pelayanan pasien. Untuk dapat menunjang keberhasilan pengembangan sistem informasi berbasis komputer pada penyelenggaraan makanan di RSMM diperlukan adanya peningkatan ketrampilan pegawai bagian gizi dalam hal komputer aplikasi melalui kursus atau pelatihan.

Analisis lebih lanjut terhadap peningkatan asuhan gizi sebagai dampak dari efisiensi penggunaan software aplikasi PKBM juga perlu dilakukan dan dikaji lebih dalam. Selain itu, dengan tersedianya software aplikasi PKBM, maka tidak harus ahli gizi yang melakukan perhitungan kebutuhan bahan makanan tersebut, sehingga ahli gizi yang ada dapat lebih dioptimalkan untuk kegiatan asuhan gizi. 


\section{RUJUKAN}

1. Departemen Kesehatan RI. Pedoman pelayanan gizi rumah sakit. Jakarta: Direktorat Jenderal Bina Kesehatan Masyarakat; 2003.

2. Nugroho E. Rekayasa sistem informasi manajemen. [Tesis]. Yogyakarta: UGM; 2008.

3. Guley HM, Stinson JP. Shceduling and resource allocation in a food service system [Abstract]. J Oper Manag1984; 4(2): 129 - 44.

4. Golzynski DL, Cash SH. Food service management formulas made easy: a self-instructional individualized unit for undergraduate dietetic students [Abstract]. J Am Diet Assoc 1997; 97(9);Suppl:1.

5. Meriwati, Haksama S. Perencanaan dan persepsi pasien pada kegiatan pengadaan makanan pasien rawat inap di Rumah Sakit Umum Daerah Dr. M. Yunus Bengkulu. The Indonesian Journal of Public Health 2006; 1(3): 73-100.

6. Setiawan A. Pengantar sistem komputer. Bandung: Informatika; 2004.

7. Sundarajan S, Srinivasan G, Staehle O, Zimmers EWJr. Application of a decision support syatem for operational decisions. Pergamon [Internet], J Comput
Ind1998;35(1-2):141-144[Accessed 26 Mei 2007]. Available from: http://www.sciencedirect.com.

8. Irmansyah F. Pengantar database. 2003 [diakses 6 Desember 2007]. [Internet]. Tersedia dalam:http:// www.llmuKomputer.com.

9. Wahyono T. Sistem informasi (konsep dasar, analisis desain dan implementasi). Yogyakarta: Graha IImu; 2004.

10. Sabarguna HBS.Sistem informasi manajemen rumah sakit. DIY: Konsorsium Rumah Sakit Islam Jateng; 2005.

11. Mukrie NA, dkk. Manajemen pelayanan gizi institusi dasar. Jakarta: Departemen Kesehatan Republik Indonesia; 1990.

12. Jogiyanto HM. Sistem teknologi informasi. Yogyakarta: Andi; 2005.

13. O'Brien JA. Introduction to information system. New York: McGraw-Hill Irwin; 2005.

14. Sullivan CF. Management of medical foodservice. Second Edition. New York: Van Nostrand Reinhold; 1990.

15. Anderson JG, Aydin CE, Jay SJ. Evaluating health care information system. London: Sage Publications; 1994. 